\title{
Learning Biotechnology Constructively and Meaningfully to Improve Personal Religious Beliefs (PRB)
}

\author{
Nur Khasanah ${ }^{1}$, Sajidan $^{2}$, Sutarno $^{3}$, Baskoro Adi Prayitno ${ }^{4}$ \\ ${ }^{1,2,3,4}$ Departement of Biology Education UIN Walisongo, Semarang \\ ${ }^{1}$ Doctoral Natural Science Education Program Universitas Negeri Sebelas Maret, Surakarta \\ ${ }^{1}$ Corresponding email: nurkhasanah@walisongo.ac.id
}

\begin{abstract}
The Background of this research is the study of the integration of science and religion in science learning in Islamic Higher Education. The study discusses how to teach biotechnology with Discovery Based Unity of Sciences (DBUS) model to improve students' personal religious beliefs. The purpose of the research is to know the implementation of Discovery Based Unity of Sciences model in learning biotechnology. The subjects of the study are majoring in biological education of UIN Walisongo Semarang and UIN Sunan Kalijaga Yogjakarta first year 2017/2018 and 2018/2019. Research method using experiment test. The results of the DBUS model study are feasible to improve PRB. The DBUS model has a loading factor value of 0.624 with a quadratic value of $0.624=0.3893$. This result means that $39 \%$ indicator of personal religious beliefs (PRB) has an effect on DBUS model. Test $t$ test on DBUS model in UIN Walisongo $t$ value is 0.862 . Test $t$ test on DBUS model in UIN Sunan Kalijaga t value is 0.861 . The DBUS model on the empowerment of UIN Walisongo and UIN Sunan Kalijaga students' PRB is high.
\end{abstract}

Keywords: integration of science, DBUS model, PRB

\section{Introduction}

In the global era of the 21st century, education in Indonesia should pay attention to ethnic, cultural, religious and social diversity so that students can learn meaningfully (Liliasari, 2007). Constructive and meaningful learning becomes a demand in learning. Constructive learning requires a more active role for students. Because of its emphasis on student activeness, the constructivist strategy is often referred to as student centered instruction. In the lecturer's classroom is helping students find facts, concepts or principles for themselves rather than giving lectures and controlling all class activities.

Meaningful learning is the process of acquiring knowledge by individuals in which specific facts relate to previously existing and stored facts in the memory of the brain. Meaningful learning has learning goals that involve more people with the world around them. Learn about more realistic things that are characterized by more active, constructive, intentional, authentic and cooperative learning. New concepts or information obtained must be linked to concepts already in the student's cognitive structure (Isjoni, 2009; Trianto, 2010). Meaningful learning is expected in addition to the cognitive aspects achieved, the religious values of students are also growing.

Personal Religious Beliefs (PRBs) are terms used to refer to the views, opinions, attitudes, and knowledge constructed by a person through interaction with the sociocultural context of living history and interpreted as a shared religion (Mansour, 2008: 2009). DRR is important to develop in order to understand events, experiences and objects on an individual level and is a social construct based on various experiences of one's life especially on religious experience. Preliminary research conducted on 20 students of Biology Education Department at UIN Walisongo, showed that student's PRB was influenced by previous education and student residence (Khasanah N. et al, 2016).

The challenge of the education world in the era of reform and technology is the strengthening of the characters in the learners. The purpose of national education, as in Law no. 20 of 2003, among them is to be a man of faith and cautious to God Almighty, and morals (Fanani M, 2015).

Islamic universities have a strategic role in realizing educational goals, by educating religious students. The importance of knowledge which is accompanied by the strength of faith and noble morality become the basis of thinking integration of science and religion in education in Islamic Higher Education (Abdullah A, 2003; 2004; Iqbal, 2012)

The recent phenomenon shows the awareness of the need to integrate the paradigm 
between science and religion, including how to teach it in the classroom (Taskin, 2014). The science of religion (Al-qur'an and Hadits) is positioned or a source of science and science as a result of experimentation and logical reasoning (Amin, 2004; Arsyad, 2009).

Higher Education and Islamic Higher Education faces challenges such as the National Standards of Education in Higher Education (SNPT) that must be met. Constraints encountered include the standard process that has not been in accordance with the expected, for it needs to get attention by doing the development process Standards. The development that can be done by an educator is by developing the learning model for the student as a prospective teacher (Candra, 2012; Silvi, 2013).

Development of learning model is expected to improve the quality of student learning and can more easily understand the basic materials of nature and biotechnology inheritance in the learning process. Learning model through discovery learning is expected to support the program of improving the quality of learning. The learning model of discovery learning or discovery is learning to discover concepts, meanings, and causal relationships through organizing learning done by learners (Burner, 2001; Arends, 2013).

The development of discovery learning model can be done through three strategies to teach critical thinking skills, namely: (1) Building Categories, (2) Finding Problem, and (3) Enhancing the Environment (Bonnie and Potts, 2003; Dracup Mary, 2012). Learning discovery learning model has a weakness in raising the assumption that the students already have concept readiness. Students who lack the concept of master, have difficulty in expressing the relationship between the concept of one with another concept, so that in turn will cause confusion. Social construction based on various experiences of one's life especially DRR less attention. Ultimately meaningful learning is also poorly implemented in the lives of everyday students (Candra, 2012; Khasanah, N et al, 2016).

Preliminary observation of research in learning activities with student discovery learning model less active and critical, seen from participation when follow practice, discussion and presentation in class. Students are still difficulties in integrating biological concepts learned with other concepts of knowledge (Khasanah, N. et al, 2015). Integrated is one approach to curriculum implementation and is applied to all levels of education (Kemendiknas, 2013). Integrated concepts involve different angles of study, up to its application and contextual. Students are expected to be able to compile knowledge from their own experience (Slavin, 2011; Dracup, 2012; Atilla et al, 2015).

The development of Unity of Sciencesbased discovery model is one of the models that help the government policy in implementing UU Sisdiknas th 2003. Through the Unity of Sciencesbased discovery model the students can gain direct experience, so that it can add strength to receive, store, and apply the concept he has learned. Students are trained to be able to find their own concepts that are learned thoroughly (holistic), meaningful, authentic and active. Research on how to implement the integrated learning paradigm of science and religion becomes interesting to do. Based on the background, it is necessary to study the Discovery based Unity of Sciences (DBUS) model to empower the personal religious beliefs (PBR).

Biotechnology includes two conventional and modern biotechnologies. Conventional biotechnology is all biotechnology products that use microorganisms to produce products and services. For example, the microorganisms used are fungi and bacteria that play a role in producing certain enzymes to perform metabolic processes in order to obtain the desired product and beneficial to humankind.

Conventional biotechnology does not use genetic engineering at all. The application of conventional biotechnology learning is based solely on experience, using simple tools, and on a small scale and conducted by communities around students. One example of a conventional biotechnology process is fermentation such as alcohol, palm mineral, soy bean, tape, oncom, and soy sauce.

Modern biotechnology is a biotechnology based on manipulation or DNA engineering, in addition to utilizing basic microbiology and biochemistry. Biotechnology based on DNA manipulation is done by modifying specific genes by transferring to different organisms such as bacteria, animals, and plants (Cambell, 2010).

The application of modern biotechnology learning is that students seek information by summarizing using sophisticated tools and 
work, done in clean and sterile conditions, better product quality, and more product quantity. Students can also observe the application of microbial work biotechnology through manipulation of the microbial genetic makeup used, for example through the insertion of genes.

Modern biotechnology learning activities include:

1) Tissue culture is a method to multiply the tissue /cells originating or obtained from the original tissue of plants first undergo mechanical, or chemical (enzymatic) separation in vitro.

2) DNA cell recombinant by reviewing articles and journals

3) Looking for information about Hybrid.

4) Use of Polymerase chains reaction (PCR) to detect and analyze nucleic acid sequences.

The DBUS model is an integrative model of discovery based on Islamic values and values of society. In learning, students are invited to explore the noble cultural values of the concept of Biotechnology. In addition, the value of religion became the basis in the implementation of the concept of biotechnology.

Achievement of learning is expected to explain the concept of biotechnology with the basis of the Qur'an, Sunnah and cultural values that exist in society. Indicators in learning include:

a. Students understand and explain the basic con-cepts of biotechnology and utilization

b. Students can implement basic concepts of bio-technology in the community.

Students are expected to be more critical in learning biotechnology by using the DBUS model. In classroom learning, students observed students' PRB. The indicator of PRB can be seen in table 1 .

Table 1. Personal Religious Beliefs (PRB) Indicator

\begin{tabular}{ll}
\hline No & \multicolumn{1}{c}{ Indicator } \\
\hline 1 & Personal Religious Epistemology \\
2 & The religious view of the purpose of science \\
3 & Religious view of the curriculum \\
4 & Scientific view of science \\
5 & Personal interpretation of religious views \\
6 & The religious view of science learning \\
7 & Characteristics of Muslim science students. \\
\hline
\end{tabular}

The dimensions of Personal Religious of Beliefs (PRB) developed include:

a. PRB linkages, teaching and learning experiences and interpretations in classroom learning

b. Experience in teaching and learning is influ-enced by PRB

c. Pedagogical beliefs are formed from teaching experience for implementation and mutual influence with the implementation of classroom teaching.

d. Knowledge and beliefs become a proverbial experience Learning as a product of the interaction between religious beliefs, classroom learning experiences (Mansour, 2008, 2009).

\section{Methods}

The design of this research is a type of quantitative research. The research method used test the effectiveness of the product with $\mathrm{T}$ test (Sugiono, 2012). The population in this study were Biology Education students UIN Walisongo (96 people) and UIN Sunan Kalijaga (94 people) in the first year of 2017/2018. This study is a population study, meaning that all populations are sampled in the study (Sujana, 2014).

This type of research is experimental with DBUS learning model as independent variable in research for experimental class and direct learning model for control class. The dependent variable is students' PRB.

The research instrument consists of learning tools, namely: Semester learning plan (RPS) and observation sheet of critical thinking skill. Learning devices are used in the implementation of learning, while the instrument of data collection as a means of data retrieval research results. The research data consist of observation of critical thinking skill of students obtained from observation done in class. All instruments are tested for validity before use. RPS and student observation sheets are tested for validity of experts in their field (judgment experts).

Instrument of observation of students' religious as 7 indicators of PRB. The research data is the value of students' critical thinking skill. Data were analized by descriptive statistic and $\mathrm{T}$ test. Descriptive analysis is used to describe the PRB of the learning model. Test T Test to test the hypothesis that has been formulated at $5 \%$ significance level. 
The use of the DBUS model in empowering $\mathrm{PRB}$ is reviewed based on the comparison of normalized gain ( $\mathrm{N}$-gain) values, between the experimental and control groups. The normalized gain ( $\mathrm{N}$-gain) can be calculated by the equation: (Mohsen Tavakol \& Reg Dennick.

2011) by the formula:

$$
\mathrm{g}=\frac{S_{\text {postest }}-S_{\text {pretest }}}{S_{\text {matssinum }}-S_{\text {pretest }}}
$$

After the normality test, the homogeneity test of variance is performed before the T Test.

Normal distributed data and homogeneous variance are obtained. Hypothesis of this research, that is: there is difference of PRB between student using DBUS model with student using conventional model. The hypothesis was tested with SPSS 18 program based on Test of Between-Subject Effects in SPSS output.

\section{Result and Discussion}

Here it is explained that $g$ is the normalized (N-gain) of both models, the maximum $\mathrm{S}$ is the ideal score of the initial and final tests, $S$ posttest is the final test score, whereas $S$ pretest is the initial test score. The normalized low $(\mathrm{N}$ gain) can be classified as follows: 0,82, the resulting $g \geq 0.7 \mathrm{~N}$-gain belongs to the high category.

Based on the results of data analysis, that there is the influence of the implementation model of discovery learning based Unity of Science (DBUS) to increase PRB. From the analysis of hypothesis testing first, there are differences PRB students who follow the model of DBUS. This is because the stages of discovery learning model of the implementation with the Unity of Science can develop a scientific attitude and understanding of the concept of general biology PRB.

The first stage, is stimulation using local wisdom, by providing the questions that are relevant in life, stimulate students to be able to think and to encourage exploration. Taking one of the divine name of relevant readings. Taking a verse in the Qur'an that are relevant. Cultivate an attitude of students to investigate their own curiosity and exploration, directing students to understand the thinking mainly about the problems that become the topic of learning (Russell, 2008).
The second stage, problem statement, the students formulate hypotheses on the questions that have been identified. When formulating hypotheses raised students' critical thinking skills towards theories used as the basis for answering the problems that arise. This attitude will bring empirical reasoning to understand the information obtained. The formulation of the problem can be derived from the problems that occur in the community that are relevant to the concept being studied. Studies by the Qur'an can also be included if there is a relevant concept (Mansour, 2008).

The third stage, the Observation data collection, the students conduct experiments. Developing students' curiosity when students conduct experiments. Students' curiosity also appears that the motivation of students to find answers to questions that arise. Critical thinking skills are emerging in the experimental activity that is honest and responsibilities of the facts found in the experiment.

Students are expected to write according to that obtained in the experiment. The ability to distinguish facts and opinions will appear in experimental activities. This stage is to train students to use scientific methods in solving problems, so it is not easy to believe in something uncertain truth (Roestiyah, 2001). Experiments also coached cooperation among students. Through experiments, students can remember longer, gaining experience learned directly so that learning becomes meaningful. According to Bruner meaningful learning will further embed more memory in the student self (Budiningsih, 2005). Suggests that the experimental method can improve the cognitive learning. interaction between the students in the experimental activities can encourage students to understand more attention objective (Aunurrahman, 2009; Melani 2012).

The fourth stage, the data processing, student discussion of the results of experiments conducted. With discussion groups of students will remember what was discussed rather than accept a direct explanation. Interaction with the environment and surrounding community schools can improve understanding and enrich their knowledge. Learning together to improve the knowledge and critical thinking (Slameto, 2010; Shirly, 2012).

Fifth stages, verification base on religion, students perform verification, repair, and justification of the results obtained through presentations and class discussions. This 
activity led to a critical attitude, confidence, a willingness to change the view of the answer because it revealed the evidence of the information that has been learned. From this activity the students will gain an understanding of a concept that has been studied (Russell, 2008). Generalization of the verses of the Qur'an, so as to increase the faith of students of meaningful learning. Discussion, argument, question skills takes place at this stage. Many references can be thought include the relevance of the Qur'an as qauliyah and natural phenomena as qauniyah (Muhyar, 2014).

Sixth stages, generalization and awareness, students draw conclusions learning outcomes. This stage can generate a willingness to change the attitude of view, because in the event set a certain concept is the result of the learning process. And the possibility of students' critical attitude in accepting the conclusion that it was decided refers to the actual concept. With the process of induction of specific things that are found in the learning process towards the common things that the conclusion, there will be a process of knowledge construction of students who briefed the concept of enabling understanding of the concept of student self (Smith, M.U, 2013).

Table 2. PRB Experiment Class UIN Walisongo T Test

Paired Samples Statistics

\begin{tabular}{ccccc}
\hline Pair & & Mean & N Std. Deviation & $\begin{array}{c}\text { Std. Error } \\
\text { Mean }\end{array}$ \\
\hline & $\begin{array}{c}\text { Post } \\
\text { test }\end{array}$ & 31.682594 & 2.06995 & .26079 \\
1 & & & & \\
& & & & \\
& Pre test 24.5079 & 94 & 2.10891 & .26570 \\
\hline
\end{tabular}

Paired Samples Correlations
\begin{tabular}{lll}
$\mathrm{N}$ & Correlation & Sig. \\
\hline 94 & .862 & .000 \\
\hline
\end{tabular}

In table 3, paired sample statistic, contains descriptive of increasing PRB UIN Walisongo between before and after using DBUS model include the amount of data, mean, standard deviation, and standard error mean.

The number of data each for the before and after given DBUS $=94$, mean (mean) before the existence of DBUS model on the increase of PRB is 24,5079 and mean (mean) level of PRB student after given DBUS is 31,6825. Standard deviation for each prior to the effect of DBUS on PRB increase of 2.10891 and thereafter is 2.06995 .

In table 4. paired sample test, contains data about whether or not there is a difference in the use of DBUS model to increase the PRB between before and after. In the paired sample test table, the data contains two t test results.

Table 3. Correlation Value

\begin{tabular}{ll}
\hline Correlation Coef & Explanation \\
\hline $0,8<$ coef $\leq 1.000$ & Height \\
\hline $0,6<$ coef $\leq 0,8$ & Enough \\
\hline $0,4<$ coef $\leq 0,6$ & Rather low \\
\hline $0,2<$ coef $\leq 0,4$ & Low \\
\hline $0<$ coef $\leq 0,2$ & Very low \\
\hline
\end{tabular}

In table 4, Paired Samples Correlations which includes $t$ count and significance. Steps taken After that is to see whether or not the influence of DBUS on the increase of student's PRB. By looking at the test results show that the correlation is $0.862>$ 0.000 .

The value of the correlation is greater than the significant value, it shows the difference of the use of DBUS model to empower the PRB student UIN walisongo. The result of correlation on $t$ arithmetic is 0.862 this shows the result of correlation on the difference of DBUS model to the increase of PRB UIN Walisongo student is High.

Table 4. PRB Experiment Class UIN Sunan Kalijaga T Test

\begin{tabular}{|c|c|c|c|c|}
\hline \multicolumn{5}{|c|}{ Paired Samples Statistics } \\
\hline & Mean & $\mathrm{N}$ & $\begin{array}{c}\text { Std. } \\
\text { Deviation }\end{array}$ & $\begin{array}{l}\text { Std. Error } \\
\text { Mean }\end{array}$ \\
\hline Posttes & 28.9570 & 93 & 2.89270 & .29996 \\
\hline Pretes & 23.7849 & 93 & 2.33056 & .24167 \\
\hline \multicolumn{5}{|c|}{ Paired Samples Correlations } \\
\hline & & $\mathrm{N}$ & Correlation & Sig. \\
\hline $\begin{array}{c}\text { Pair } \\
1\end{array}$ & $\begin{array}{l}\text { postes \& } \\
\text { pretes }\end{array}$ & 93 & .861 & .000 \\
\hline
\end{tabular}


In the 5 paired sample statistic table, it contains descriptive of the increasing of Sunan Kalijaga PRB between before and after DBUS model covering the amount of data, mean, standard deviation, and standard error mean.

The number of data each for the before and after given DBUS $=93$, mean (mean) before existence of DBUS model to empower the DRR is 23,7849 and mean (mean) level of PRB student after given lesson with DBUS model is 28.9570. Standard deviation for each prior to the influence of the DBUS model on the DRR increase of 2,892 and subsequent 2.33056.

In table 5 paired sample test, it contains data about whether or not there is any difference in using DBUS model to empower the PRB between before and after.

In the Paired Samples Correlations table 4, that includes $\mathrm{t}$ count and significance. Steps taken After that is to see whether or not the influence of DBUS on the increase of student's PRB. By looking at the test results indicate that the correlation is $0.861>0.000$. The value of the correlation is greater than the sig value, it indicates the difference of the use of DBUS model to empower the student's PRB UIN Sunan Kalijaga. The result of correlation on $t$ arithmetic is 0.861 this shows the result of correlation on DBUS model to empowerment of PRB student UIN Sunan Kalijaga is high.

The effect size is the magnitude of the effect caused by the parameters tested in the test. The size of the effect depends on the type of parameter being tested. Parameter effect size in this study is to test the correlation coefficient then the effect size is determined by how big the difference. The way to calculate the effect size in this study was to use an average of Cohen. According to Cohen, the average effect size is the mean difference expressed in standard deviation units. Effect size d Cohen $=$ (average difference) / (standard deviation) So the result of effect size in this research are:

\section{a. Effect size d Cohen Result from UIN Walisongo}

Table 5. Experiment $\mathrm{T}$ Test in UIN Walisongo

\begin{tabular}{cl}
\hline Mean size & Std. Deviati on \\
\hline 4,95833 & 5,2814 \\
\hline
\end{tabular}

effect size Model DBUS in UIN Walisongo equal to $\mathrm{d}=4.95833 / 5.2814=$ 0.9388287

\section{b. Effect size d Cohen Result from UIN Sunan Kalijaga}

Table 6. Experiment $\mathrm{T}$ Test in UIN Sunan Kalijaga

\begin{tabular}{ll}
\hline Mean size & Std. Deviati on \\
\hline 9,18085 & 3,47947 \\
\hline
\end{tabular}

The result of measure size of DBUS model size in UIN Sunan Kalijaga is d $=9,18085$ / $3,47949=2,63857714$

Based on Cohen's effect size criteria proposed by Cohen on the size of the effect are as follows: $\mathrm{d}>0.8$, Large effects (average difference of more than 0.8 standard deviation).

So it can be concluded that the effect size of the DBUS model both in UIN Walisongo and UIN Sunan Kalijaga in the class of great effect because it has a value $\mathrm{d}>0.8$ ie 0.93 in UIN Walisongo and 2.63 from UIN Sunan Kalijaga.

In the second hypothesis test is found, that there are differences significantly PRB students who follow the model of DBUS.

In addition, the syntax of stimulation using local wisdom, verification base on religion, and generalization and awareness, very empowering, because the syntax will generate new information and new concepts and implamentation in personal relgion belief and society.

Understanding the interpretation on the model of direct teaching is low, because the model is not visible any syntax that directs the activities of students in data collection to be interpreted more as a conclusion. Students to explain the meaning of the information, because the direct teaching models are syntax on the delivery of training students to elaborate on their knowledge through the tasks given. Learning was limited to transfering information to students without any understanding of the information.

The thing is not so basic enough knowledge to students, resulting in the student's knowledge limited to the rote and students will be less able to make predictions of phenomena that exist. Students can further increase the personal religion belief by implementing the basic biology concept that is understood by the Quran in their life, so that students learn more meaningful (Mansour N, 2008, 2009). 


\section{Conclusion}

The findings in this study is a learning model affect the general understanding of biological concepts and critical thinking skills of students. Detail described as follows: (1) there are difference in the value of critical thinking skills significantly between groups of students who implementation with the DBUS model and group who learn by direct teaching model. (2) Test of $\mathrm{t}$ test on DBUS model in UIN Walisongo from result of correlation at $\mathrm{T}$ test is 0,862 it shows result of correlation on influence of DBUS to increase of PRB student UIN Walisongo is High. Test of t test on DBUS model in UIN Sunan Kalijaga from result of correlation at $\mathrm{T}$ test is 0,861 it shows result of correlation at DBUS model to empowerment of student PRB UIN Sunan Kalijaga is high.

The effect size of the DBUS model including the category has a big effect because it has a value $\mathrm{d}>0.8$ ie $\mathrm{d}=0.93$ in UIN Walisongo, and $\mathrm{d}=2.63$ in UIN Sunan Kalijaga.

\section{Preferences}

Amin Abdullah, dkk., 2004. Integrasi Sains Islam Mempertemukan Epistemologi Islam dan Sains.

Yogyakarta: Pilar Relegia dan SUKA Press

Amin Abdullah, dkk. 2003. Menyatukan Kembali Ilmu-IImu Agama dan Umum, Yogyakarta: SUKA Press.

Arsyad, Azhar dkk. 2009. Membangun Universitas menuju Peradaban Islam Modern. Makassar: Alauddin Press

Arends. 2013. Learning to Teach I (Terjemah Made Frida

Yulia), Jakarta: Salemba Humanika

Arikunto, S. 2002. Prosedur Penelitian. Jakarta: PT. Rineka Cipta

Aunurrahman. 2009. Belajar dan Pembelajaran. Bandung: Alfabeta

Barbour, Ian G. 2006. Issue in Sciense andreligious, terj. Damayanti, Ridwan, Isu dalam Sains dan Agama. Yogyakarta: UIN Sunan Kalijaga.

Bagir, Zainal Abidin, et al. 2005. Integrasi Ilmu dan Agama Interpretasi dan Aksi, Mizan, Bandung: Mizan.

Budiningsih. 2005. Model Pembelajaran Penemuan (Discovery Learning), Kementerian Pendidikan dan Kebudayaan Tahun 2013.

Campbell Neil A., Mitchell and Reece. 2010.

Biologi. Jilid 1 s.d 3,Edisi Kedelapan, Jakarta: Erlangga

Charbel N. El-Hani Æ Claudia Sepulveda. 2010. The relationship between science and religious in the education of protestant biology preservice teachers in a Brazilian university. Cult Stud of Sci Educ 5:103125

Daryanto. 2014. Pendekatan Pembelajaran Saintifik Kurikulum 2013. Yogyakarta: Gava Media.

Dike, Daniel. 2009. Peningkatan Kemampuan Berpikir Kritis Siswa dengan Model TASC (Thinking Actively in a Social Context) pada Pembelajaran IPS. Jurnal Pendidikan, 1(1), 15-29.

Dracup Mary. 2012. Designing online role plays with a focus on story development to support engagement and critical learning for higher education students. Journal of Learning Design Vol.5

Dahar, R. W. 1989. Teori-Teori Belajar. Jakarta: Erlangga.

Jeanne Ting Chowning, Joan Carlton Griswold, Dina N. Kovarik, Laura J. Collins. 2012 Fostering Critical Thinking, Reasoning, and Argumentation Skills through Bioethics Education, PLoS ONE.

Hair, J. F., Black, W. C., Babin, B. J., Anderson, R. E., \& Tatham, R. L. 2006. Multivariate data analysis 6th ed. Uppersaddle River: Pearson Prentice Hall.

Gamal Abdul Nasir Zakaria and Salwa Mahalle. 2012.

Innovation and Creativity in Teaching Islamic Religious Knowlege (IRK) at Secondary Schools in Brunei Darussalam. International Journal of Arts \& Sciences: 5(5):239-252 University Publications. Net

Hosnan. 2014. Pendekatan Saintifik dan Kontekstual dalam Pembelajaran Abad 21. Bogor: Ghalia Indonesia.

Isjoni. 2009. Cooperative Learning. Bandung: Alfabeta.

Jesse Bazzul. 2014. Tracing "Ethical Subjectivities" in Science Education: How Biology Textbooks Can Frame EthicoPolitical Choices for Students. Journal Res Sci Educ. DOI 10.1007/s11165-014-9411-4

Kemendikbud. 2013. Materi Pelatihan Guru, Implementasi Kurikulum 2013. Jakarta: Kementerian Pendidikan dan Kebudayaan

Khasanah N, et al 2016. The discovery learning model and the implementation of learning with the unity of sciences in basic biology course to increase critical thinking skills. 
Proceedings of the Asian Education Symposium 2016. AES 2016, Bandung, Indonesia, 22-23 November 2016.

Khasanah N, et al. 2017. Influence integrated science model and implamantation learning with the unity of science in basic biology course to increase critical thinking. International Journal of Science and Applied Science: Conference Series. UNS

Lin, Yu-Mei \& Lee, Pei-Chen. 2013. The Practise of Business's Teaching: Perspective from Critical Thingking. International Journal of Business and Commerce, 2 (6), 52-58.

Liliasari. 2007. Scientific Concept and Generic Science Skill Relationship in the $21^{\text {st }}$ Century Science Education. Bandung: SPS UPI

Masek \& Yamin. 2011. The Effect of Problem Learning on Critical Thinking Ability: A Theoretical and Empirical Review. Internasional Review of Sosial Sciences and Humanities. 2 (1). 215-221

Mansour N. 2008. The Experiences and Personal Religious Beliefs of Egyptian Science Teachers as a Framework for Understanding the Shaping and Reshaping of their Beliefs and Practices about ScienceTechnology-Society (STS). International Journal of Science Education. Vol. 30, No. 12, 5 October 2008, pp. 1605-1634

Mansour,N.2009. Science Teachers' Beliefs and Practices: Issues, Implications and Research Agenda, International Journal of Environmental \& Science Education Vol. 4, No. 1: 25-48.

Mohsen Tavakol and Reg Dennick. 2011.

Making Sense of

Cronbach's Alpha. International Journal of Medical Education. 2011

Muhyar F. 2012 Integrasi Sains dan Agama (Strategi Konvensi IAIN Walisongo Menjadi UIN Walisongo), Semarang: Seminar Nasional.

Muh Khalifah Mustami. Genetika. Makassar. UIN Alauddin Makassar. 2013

Silvi. 2013. Pendekatan Ilmiah dalam Pembelajaran-Bahan Pelatihan Nasional. Hotel Siliwangi 18 September 2013

Taskın. O. 2014. An exploratory examination of Islamic values in science education: Islamization of science teaching and learning via constructivism. Cult Stud of Sci Educ 9:855-875
Tsai. C. 2002. Nested epistemologies: science teachers' beliefs of teaching, learning and science. International Journal of Science Education, 24(8), 771-783.

Purwanto. 2013. Evaluasi Hasil Belajar. Yogyakarta: Pustaka Pelajar

Robert. E. Slavin, Penerjemah Marianto Samosir. 2011. Psikologi Pendidikan: Teori dan Praktik, Edisi Ke-9, Jakarta, PT. Indeks

Roestiyah. 2008. Strategi Belajar Mengajar. Jakarta: Rineka Cipta.

Russell A .2008. Theology in Ecological Perspective: An Interdisciplinary, InquiryBased Experiment, Teaching Theology and Religion, vol. 11 no. 1, pp 42-53.

Sanjaya, W. 2006. Strategi Pmbelajaran. Jakarta: Prenada Media Group.

Scott Abbott and Daniel J. Fairbanks. 2016. Experiments on Plant Hybrids by Gregor Mendel. Genetics, Vol. 204, 407-422 October 2016.

Schunk, Dale H. 2012. Learning Theories. Jakarta: Pustaka belajar.

Sudjana, Nana. 2014. Penilaian Hasil Proses Belajar Mengajar. Bandung: PT. Remaja Rosdakarya.

Suryo. Genetika Manusia. 2011. Yogyakarta. Gadjah Mada University Press

Slameto. 2010. Strategi Belajar Mengajar. Jakarta : Rhineka cipta

Smith, M.U (2013). The Role of Authority in Science and Religion with Implications for Science Teaching and Learning. Journal Sci \& Educ (2013) 22:605-634 DOI 10.1007/s11191-0129469-1.

Trianto. 2007. Model-model Pembelajaran Inovatif Berorientasi Konstruktif, Jakarta: Prestasi Pustaka. Tsai, C. 2002. Nested epistemologies: Science Teachers' Beliefs of Teaching, Learning and Science. International Journal of Science Education, 24(8), 771783.

Widiadnyana I W., Sadia I W., Suastra I W. 2014. Pengaruh Model Discovery Learning Terhadap Pemahaman Konsep IPA dan Sikap Ilmiah Siswa SMP, eJournal Program Pascasarjana Universitas Pendidikan Ganesha Program Studi IPA (Volume 4 Tahun 2014).

Wilis, Ratna. 2006. Teori-Teori Belajar dan Pembelajaran.

Bandung: PT Gelora Aksara Pratama. 